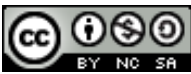

https://doi.org/10.31743/abmk.9761

\title{
OFIARNOŚĆ DUCHOWIEŃSTWA I SKŁADKI KOŚCIELNE (PARAFIALNE) NA RZECZ ZWIĄZKU CARITAS DIECEZJI TARNOWSKIEJ W LATACH 1939-1945
}

\begin{abstract}
Streszczenie
Po początkowej destabilizacji akcji ofiarności Kościoła w diecezji tarnowskiej (subwencje kurii, osobiste datki księży i ofiary wiernych z parafii) na rzecz Caritas (głównie centrali) od 1942 r. obserwuje się wyraźny wzrost datków na tarnowską Caritas. Najszersze rozmiary przybrała akcja ofiar parafialnych (gotówka, naturalia) na centralę Caritas. W latach 1942-1944 na cele społeczne gotówkę i naturalia przekazywało ok. 30 parafii (ok. 30\%), które znajdowały się na terenie 15 dekanatów (52\%). Ogółem przekazano 351445 zł, głównie z parafii w środkowym i zachodnim pasie diecezji tarnowskiej. Ofiarność duchownych z osobistych dochodów (iura stolae) kulminację osiągnęła w 1944 r., kiedy to ponad 480 księży (wobec $88 \mathrm{w} 1940$ r.) przekazało Caritasowi ponad 320 tys. zł. Wsparcie finansowe i rzeczowe, jak i datki wiernych na rzecz oddziałów parafialnych Caritas nie przybrały charakteru powszechnego, obserwowano raczej odosobnione przypadki na terenie diecezji tarnowskiej. Lokalnie jednak środki te były podstawą budżetu oddziałów, stanowiąc niekiedy nawet $3 / 4$ jego dochodów. Subwencje kurii tarnowskiej, dzięki polityce finansowej bp Komara, stanowiły najpoważniejszą pozycję w budżecie Caritas. Do 1944 r. kuria przekazała 2472000 zł. Było to prawie 60\% ogółu przychodów Związku, ponad 78\% zaś wszystkich ofiar ze strony Kościoła na stowarzyszenie. Słowa kluczowe: II wojna światowa; Kościół katolicki; diecezja tarnowska; Caritas
\end{abstract}

* Jerzy Gapys - dr hab. historii; prof. UJK, Instytut Historii, Uniwersytet Jana Kochanowskiego w Kielcach

e-mail: jgapys@ujk.edu.pl

https://orcid.org/0000-0003-0097-0771 
$* * * * *$

Na progu XX wieku pojawiły się prądy, które dążyły do instytucjonalizacji i centralizacji akcji charytatywnej Kościoła katolickiego ${ }^{1}$. W Polsce te tendencje nasiliły się po $1918 \mathrm{r}^{2}$, by w latach 30 . XX wieku przybrać formy instytucjonalne ${ }^{3}$. W tym okresie z inicjatywy hierarchów we współpracy z duchowieństwem powołano w większości diecezji Związki Diecezjalne Caritas, w niektórych z nich z szeroko rozbudowaną strukturą parafialną. Najlepiej rozwinięta sieć oddziałów parafialnych istniała w Wielkopolsce i Kujawach oraz w Małopolsce Zachodniej (głównie diecezja tarnowska) ${ }^{4}$.

Tuż przed wybuchem II wojny światowej Związek funkcjonował w 12 (archi)diecezjach ${ }^{5}$. Po klęsce wrześniowej w 1939 r. wraz z dezintegracją struktur kościelnych został on zlikwidowany przez okupantów na ziemiach wcielonych do Rzeszy i do Związku Sowieckiego. Caritas przetrwał (choć nie na długo) tylko na terenie Generalnego Gubernatorstwa (dalej: GG) ${ }^{6}$. W końcu 1939 r. funkcjonowało 11 central diecezjalnych (archidiecezjalnych): Lwów, Przemyśl, Tarnów, Kraków, Kielce, Sandomierz, Lublin, Łódź, Częstochowa, Warszawa i Siedlce? $\mathrm{W}$ ich ramach istniało prawie pół tysiąca oddziałów, w tym najwięcej w diecezji

${ }^{1}$ E. Leś, Od filantropii do pomocniczości. Studium porównawcze rozwoju i działalności organizacji społecznych, Warszawa 2000, s. 46-96; por. Cz. Kępski, Idea miłosierdzia a dobroczynność i opieka, Lublin 2002, s. 53-58.

${ }^{2}$ Choć od początku XX wieku obserwuje się tendencje do specjalizacji, a jednocześnie koordynacji pracy charytatywnej; por. J. Majka, Chrześcijańska myśl i ruch charytatywny, w: Historia katolicyzmu spolecznego w Polsce 1832-1939, red. Cz. Strzeszewski, R. Bender, K. Turowski, Warszawa 1981, s. 513; S. Wilk, Episkopat Kościoła katolickiego w Polsce w latach 1918-1939, Warszawa 1992, s. 312-320; por. P. Kurlenda, Działalność dobroczynna Kościoła katolickiego w Wielkopolsce i na Pomorzu w latach 1919-1939, Torun 2001, s. 92-100.

${ }^{3}$ I Synod Plenarny w Częstochowie (1936 r.) nakazywał powoływanie w każdej parafii Caritasu, a duchownych zobowiązał do zachęcania osób świeckich do angażowania się w dzieła miłosierdzia chrześcijańskiego; zob. W. Wójcik, Ze studiów nad synodami polskimi, Lublin 1982, s. 194-220; E. Sugier, Odpowiedzialność Kościoła za ubogich i chorych w świetle kościelnego prawodawstwa partykularnego w Polsce międzywojennej, Koszalin 2001, s. 38-42.

${ }^{4}$ Większość oddziałów parafialnych Caritasu funkcjonowało przede wszystkim w środowisku miejskim, wieś pod tym względem była zaniedbana, Archiwum Kurii Metropolitarnej w Krakowie (dalej: AKMK), Teki Sapieżyńskie (dalej: TS), TS XXVII/26, Ogólnopolski Zjazd Dyrektorów Diecezjalnych Związków „Caritas” w Poznaniu 23 II 1937; Caritas. Miłosierdzie Chrześcijańskie w parafii. Katolickie Towarzystwo Dobroczynności Diecezji Płockiej „,Caritas”, Płock 1935; A. Gretkowski, Katolicyzm społeczny na przykładzie działalności charytatywno-społecznej $w$ diecezji płockiej w I polowie XX wieku, Płock 2001.

${ }^{5}$ J. Majka, Kościelna działalność dobroczynna w Polsce w XIX i pierwszej połowie XX wieku, „Zeszyty Naukowe KUL”, 9 (1966) nr 1-2, s. 133; tenże, Chrześcijańska myśl i ruch charytatywny, s. 520.

${ }^{6}$ Cz. Madajczyk, Generalna Gubernia w planach hitlerowskich. Studia, Warszawa 1961, passim.

${ }^{7}$ P. Aleksandrowicz, Diecezja siedlecka czyli podlaska $w 150$ rocznicę erekcji (1818-1968). Przyczynki i materiaty do dziejów Diecezji Siedleckiej czyli Podlaskiej, Siedlce 1971, s. 250-251; Archiwum Diecezjalne w Siedlcach (dalej: ADSP), Caritas, t. 3, 1931-1948. 
tarnowskiej $-280^{8}$, tj. praktycznie we wszystkich parafiach ${ }^{9}$. Pod koniec wojny istniało już tylko 5 central diecezjalnych z ok. 363 oddziałami parafialnymi. Działały one jako sekcje Rady Głównej Opiekuńczej (dalej: RGO) ${ }^{10}$. Tarnowska Caritas była najsilniejszą sekcją RGO na terenie GG, zachowała własną strukturę i część form oraz metod działania ${ }^{11}$. Związek w Tarnowie prowadził szeroką działalność, m.in. niósł pomoc wysiedlonym z Wielkopolski i uchodźcom z Warszawy po powstaniu warszawskim, prowadził kuchnie dla ubogich i ochronki, udzielał zapomóg dla potrzebujących itp. Ogółem Związek Caritas Diecezji Tarnowskiej wydał w czasie II wojny światowej na pomoc dla potrzebujących 9220311 zł².

Skąd Związek czerpał środki? Statut Caritasu przewidywał różnorodne źródła pozyskiwania funduszy: składki członkowskie ${ }^{13}$, ofiary społeczne, darowizny i dochody niestałe (np. organizacja imprez) ${ }^{14}$. Włączenie w struktury RGO umożliwi-

${ }^{8}$ Archiwum Akt Nowych w Warszawie (dalej: AAN), Rada Główna Opiekuńcza 1939-1945 (dalej: RGO), sygn. 731, k. 78.

${ }^{9}$ Archiwum Diecezji Tarnowskiej (dalej: ADT), Caritas, sygn. Car O 1941, Opis majątku Związku „Caritas” Diecezji Tarnowskiej, z dn. 25 kwietnia 1941 r.

${ }^{10}$ Niektóre opracowania dotyczące Kościoła sugerują, że do końca wojny „Caritas” był samodzielną organizacją, co jednak nie jest zgodne z rzeczywistością, B. Kumor, Historia Kościoła, cz. 8: Czasy współczesne 1914-1992. Kościót katolicki w okresie systemów totalitarnych i odnowy soborowej, zniewolenie Kościołów wschodnich, sekularyzacja i rozdrobnienie Kościołów i wspólnot protestanckich, Lublin 1995, s. 467; B. Kroll, Rada Główna Opiekuńcza 1939-1945, Warszawa 1985, s. 71; Z. Fijałkowski, Kościót katolicki na ziemiach polskich w latach okupacji hitlerowskiej, Warszawa 1983, s. 180-181; Związek Caritas rzeczywiście do 1941 roku działał jako samodzielna organizacja. Od wiosny 1941 r. centrale diecezjalne utraciły jednak samodzielność na rzecz RGO i funkcjonowały jako Sekcje Charytatywne Rady, a w zasadzie komitety opiekuńcze, niekiedy nawet delegatury. Rada przejęła też cały majątek związków, J. Gapys, Działalność charytatywna duchowieństwa diecezjalnego w Generalnym Gubernatorstwie 1939-1945, Kielce 2012, s. 126; AKMK, TS XXVII/29, Sprawozdanie z akcji dobroczynnej Caritas Diecezji Tarnowskiej za lata 1939-1944.

${ }^{11}$ Po krótkotrwałym chaosie organizacyjnym spowodowanym działami wojennymi w następnych latach sieć tarnowskiej Caritas została odbudowana. W latach 19441-1944 w parafiach istniało 280 oddziałów, AAN, RGO, sygn. 731, k. 78.

${ }^{12}$ M. Podgórski, Powstanie i pierwsze lata działalności Caritas diecezji tarnowskiej, w: Misericors - 75 lat działalności Caritas diecezji tarnowskiej, red. P. Grzanka, Tarnów 2012, s. 274-277; R. Podstołowicz, P. Grzanka, Wczoraj i dziś Caritas diecezji tarnowskiej, w: Misericors - 75 lat działalności Caritas diecezji tarnowskiej, red. P. Grzanka, Tarnów 2012, s. 325-326; S. Wójtowicz, Zwiazek ,Caritas” Diecezji Tarnowskiej w stużbie bliźnim w latach 1939-1950, w: Dzieje diecezji tarnowskiej Instytucje i wydarzenia, t. 2, red. A. Gąsior, J. Królikowski, Tarnów 2012.

${ }^{13}$ Członkiem mogły być instytucje i zakłady dobroczynne, fundacje, organizacje społeczne, parafie rzymskokatolickie oraz osoby prywatne wyznania rzymskokatolickiego. Przewidywano kilka rodzajów członkostwa, tj. członek zwyczajny, honorowy, dożywotni i wspierający.

${ }^{14}$ AKMK, TS XXVII/29, Statut „Caritas” Diecezji Tarnowskiej. Opis dzieł miłosierdzia w latach wojny 1939-1944; Archiwum Narodowe w Krakowie (dalej: ANK), Związek Stowarzyszeń i Zakładów Dobroczynnych, Wychowawczych i Opiekuńczych Archidiecezji Krakowskiej „Caritas” z lat 1934-1940 (dalej: ZSiZDWiOADK), Statut Związku „Caritas” Diecezji Tarnowskiej 1937 rok; sygn. ZC- 1, k. 517-549. 
ło organizacji nie tylko prowadzenie akcji opiekuńczej ${ }^{15}$, ale też dawało podstawy do legalnego pozyskiwania środków na działalność. Obok ofiar społecznych Caritas mógł korzystać z subwencji komitetów opiekuńczych i centrali RGO oraz lokalnej administracji ${ }^{16}$. W diecezji tarnowskiej znaczną część funduszy Związek czerpał z ofiarności społecznej. Analizując ją, da się zauważyć, że datki na Caritas przekazywały różnorodne grupy społeczne: chłopi, ziemianie, inteligencja, przedsiębiorcy i duchowieństwo ${ }^{17}$. Odbywało się to w sposób zorganizowany, tj. stałe comiesięczne składki członkowskie, zbiórki żywnościowe oraz tace parafialne. Celem opracowania jest przeanalizowanie ofiarności duchowieństwa katolickiego $^{18}$ i wspólnot parafialnych na rzecz Caritasu w diecezji tarnowskiej w latach 1939-1945. Datki tych ostatnich były traktowane jako oblationes fidelium - czyli jako ofiary złożone Bogu, jako własność Boga, którą mógł dysponować jedynie biskup, czyli Kościół, którego reprezentantem w parafii był proboszcz ${ }^{19}$.

Duchowieństwo diecezji tarnowskiej spieszyło z pomocą materialną stowarzyszeniu na dwa sposoby: przekazywało ofiary z osobistych dochodów (iura stolae) oraz z funduszy parafialnych. Na te ostatnie składały się datki z dochodów majątku parafii (np. z ziemi), taca (składki kościelne) i zbiórki do puszek oraz zsypki żywności. Księża byli zobligowani do wsparcia Diecezjalnego Związku Caritas diecezji tarnowskiej (centrali) oraz mogli przeznaczać też dochody własne i parafii na działalność oddziałów (oddziały prawnie były częścią stowarzyszenia) ${ }^{20}$.

${ }^{15}$ Okupant niemiecki w 1940 r. rozwiązał i zakazał działania polskim organizacjom politycznym, społecznym, wojskowym, akademickim i religijnym, AKMK, TS XXVI/129, Rozporządzenie o stowarzyszeniach w GG z dn. 23 VII 1940; TS XXVI/132, Sprawa rozwiązania stowarzyszeń, w tym religijno-charytatywnych - analiza VIII 1940 r. Zdarzało się, że wykorzystując zakaz zgromadzeń publicznych, władze nie dopuszczały do zakładania oddziałów parafialnych Caritasu; Gapys, Działalność charytatywna duchowieństwa, s. 102.

${ }^{16}$ Gapys, Działalność charytatywna duchowieństwa, s. 96-97, 104, 119-127; Kumor, Historia Kościoła, s. 467; Kroll, Rada Główna Opiekuńcza, s. 71; Z. Fijałkowski, Kościół katolicki na ziemiach polskich $w$ latach okupacji hitlerowskiej, Warszawa 1983, s. 180-181; J. Gapys, „Caritas” $w$ diecezji kieleckiej w latach II wojny światowej, w: Dobroczynność i pomoc społeczna na ziemiach polskich w XIX i XX i na poczatku XXI wieku, t. 2, red. M. i M. Przeniosło, Kielce 2010, s. 177-178.

${ }^{17}$ Gapys, Działalność charytatywna duchowieństwa, s. 139 i nn.

${ }^{18} \mathrm{Na}$ progu wojny i okupacji w diecezji tarnowskiej pracowało 622 księży diecezjalnych (w tym 499 duchownych w duszpasterstwie parafialnym) i 54 kapłanów zakonnych. Diecezja była podzielona na 28 dekanatów (29 od 1940 r.) i 283 parafie. W diecezji znajdowało się 44 miasta i miasteczka (w tym Tarnów i Nowy Sącz przekraczały 25 tys. mieszkańców) i 1309 wsi. Liczba ludności katolickiej (wraz z grekokatolikami) wynosiła ok. 1 mln osób. B. Kumor, Diecezja Tarnowska i jej stan w 1939 r. Zarząd i organizacja diecezji. Duchowieństwo 1939-1945, w: Życie religijne w Polsce pod okupacją hitlerowska 1939-1945, red. Z. Zieliński, Warszawa 1982, s. 254-258.

${ }^{19}$ ADT, Caritas, sygn. CarO 1944, Pismo kurii tarnowskiej w sprawie świadczeń parafii na rzecz Kościoła, 1944 r.; Gapys, Działalność charytatywna, s. 11-12.

${ }^{20}$ AKMK, TS XXVII/29, Statut „Caritas” Diecezji Tarnowskiej 1939. 


\section{Ofiary osobiste duchowieństwa na Związek Caritas Diecezji Tarnowskiej}

Księża w diecezji tarnowskiej jeszcze przed wybuchem II wojny światowej mieli status członków wspierających i na tej podstawie byli zobowiązani do corocznej składki na rzecz centrali tarnowskiej Caritas ${ }^{21}$. Dokonywano jej na zasadzie rocznego ryczałtu - jego wysokość ustalona była na 5 zł miesięcznie. Ofiary te regulowane były z osobistych dochodów duchowieństwa - iura stolae. W sierpniu 1939 r. na rachunek centrali w Tarnowie wpłynął ryczałt od księży członków Caritasu w kwocie 2380 zł. Pochodził on od 476 duchownych $(95,4 \%$ ogółu kleru w parafiach), składka od jednego kapłana wynosiła 5 zł. Dodatkowo wśród uiszczających składkę znalazło się grono kilku księży katechetów. Najwyższą składkę przekazał ks. Walenty Chrobak - 100 zł, po 5 zł złożyli: ks. Andrzej Niwa, ks. dr Jędrzej Cierniak, ks. Stanisław Gazda, ks. Piotr Warecki i ks. Adam Stefański. Ogółem składka na Caritas od duchownych w diecezji wyniosła 2505 zł22.

Wybuch wojny, przebieg działań zbrojnych, organizowanie systemu okupacyjnego (m.in. rozwiązanie i zakaz działania organizacji polskich) ${ }^{23}$ oraz niemiecka polityka gospodarcza i ludnościowa doprowadziły do destabilizacji w działalności Caritas. Postępująca pauperyzacja wiernych, jak również duchowieństwa ${ }^{24}$ spowodowała, że drastycznie zmniejszyła się liczba księży opłacających składkę, choć kwota była tylko nieco niższa ${ }^{25}$. W pierwszym półroczu 1940 r. kapłani na Caritas przekazali 1910 zł. Suma wprawdzie była jedynie o 1/4 niższa, ale z punktu widzenia Związku co innego niepokoiło, tj. liczba księży regulująca składki. Składkę wpłaciło tylko 27 kapłanów - 5,4\% duchownych w parafiach (w tym 8 nazwisk księży powtarza się na dwóch listach ofiarodawców $)^{26}$. Kwoty były wprawdzie kilkakrotnie wyższe w stosunku do sierpnia 1939 r., ale ich realna wartość w związku z inflacją ${ }^{27}$ i ogromnymi potrzebami opiekuńczymi była nie-

${ }^{21}$ Warto dodać, że np. w diecezji kieleckiej tamtejszy biskup nałożył na księży 10 \% podatek od iura stolae na Caritas, Gapys, , Caritas” w diecezji kieleckiej, s. 188.

${ }^{22}$ ADT, Caritas, sygn. Car 0 1941, Do rachunku F.Z. J, sierpień 1939 r.

${ }^{23}$ AKMK, TS XXVI/129, Rozporządzenie o stowarzyszeniach w GG z dn. 23 VII 1940; TS XXVI/132, Sprawa rozwiązania stowarzyszeń, w tym religijno-charytatywnych - analiza VIII $1940 \mathrm{r}$

${ }^{24}$ Do parafii w całym GG trafiły setki księży wysiedlonych, część z nich była na utrzymaniu parafii, inni w ramach pomocy zostali przydzieleni do pracy duszpasterskiej w poszczególnych parafiach. Skutkowało to niższymi dochodami miejscowego kleru; por. Gapys, Działalność charytatywna, s. 71-76.

${ }^{25} \mathrm{Nie}$ wiadomo, czy była to jedynie krótkotrwała destabilizacja systemu ryczałtowego poboru daniny, czy załamanie było dłuższe. Statystyka dostępna dla kolejnych lat działalności Caritas każe domniemywać, że było ono trwałym zjawiskiem. Dane statystyczne odnośnie do ofiarności kleru z osobistych dochodów pojawiają się dopiero w sprawozdaniu finansowym z 1944 r. Jest to znów dobrze działający system, ponieważ księża z terenu diecezji przekazali na centralę Caritas ponad 300 tys. zł. Trudno wyjaśnić, dlaczego nie było żadnych wpłat w latach 1941-1943. Prawdopodobnie koncentrowano się na ofiarności wiernych, o czym dalej w opracowaniu.

${ }^{26}$ ADT, Caritas, sygn. Car0 1940, Do rachunku F.Z. 91/40; Do rachunku F.Z. 92/40.

${ }^{27}$ Szczególnie była odczuwalna zwyżka cen artykułów spożywczych i ziemiopłodów. W stosunku do okresu przedwojennego zanotowano wzrost: pod koniec 1939 r. 3-krotny, w 1940 r. 8-krotny, w 1941 r. 20-krotny, w 1942 r. 50-krotny, w 1943 r. 70-krotny, w 1944 r. 130-krotny; S. Smoliń- 
wystarczająca. Na ogół jeden ksiądz wpłacał 60 zł na poczet składki, choć w trzech przypadkach (ks. Zygmunt Jakus, ks. Stanisław Wójtowicz, ks. Stanisław Kobos) przekazano po 75 zł. Dwóch księży opłaciło tylko połowę składki, czyli 30 zł (ks. Józef Kuczek, ks. Jan Żurek), a jeden nawet mniej - 25 zł (ks. Stefan Dobrzański) ${ }^{28}$. Na kolejnej liście powtarza się 8 nazwisk księży, którzy kontynuowali składki. Było to w dużej mierze duchowieństwo wyższe (proboszczowie, dziekani, kanonicy). W pierwszym półroczu po raz drugi składkę uregulowali następujący księża: dziekan Józef Slazyk, kan. Jan Wałęcki, kan. Mikołaj Pichura i kan. Józef Badowski²9.

Tabela 1. Liczba księży członków wpierających i wysokość składki na Związek Caritas Diecezji Tarnowskiej w 1940 r.

\begin{tabular}{|c|c|c|c|}
\hline Lata & Liczba księży & $\begin{array}{c}\text { \% księży } \\
\text { w parafiach }\end{array}$ & Suma w zl \\
\hline I półrocze 1940 & 27 & 5,4 & 1910 \\
\hline II półrocze & 61 & 12,2 & 3545,3 \\
\hline Ogółem & 88 & 17,6 & 455,30 \\
\hline
\end{tabular}

Źródło: ADT, Caritas, sygn. Car0 1941, Do rachunku F.Z. J, sierpień 1939 r.; sygn. Car0 1940, Do rachunku F.Z. 91/40; Do rachunku F.Z. 92/40; Do rachunku F.Z. 109/40; Do rachunku F.Z. 110/40; Do rachunku F.Z. 122/40; Do rachunku F.Z. 144/40.

Kolejne dwa kwartały 1940 r. to lekka tendencja wzrostowa, tak w zakresie kwotowym, jak i liczby członków opłacających składki. Od września do grudnia 1940 r. składki ogółem wpłaciło 61 kapłanów, na sumę 3545,30 zł. (tabela 1). Dominowały wpłaty rzędu 60 złotych, choć zdarzały się datki w znacznie niższej kwocie - 10, 15, 30 czy 40 zł. Co najmniej kilku księży wpłaciło po 70-75 zł, dwóch po 100 zł (ks. Władysław Lassowski i ks. Jan Kozioł). Co istotne, pochodziły one w każdym miesiącu od innych księży, poza jednym przypadkiem ks. Piotr Stary opłacił składkę za wrzesień i za listopad 1940 r. ${ }^{30}$ Powyższe dane jednoznacznie wskazują, że w 1940 r. nie istniał na terenie diecezji regularny pobór składki od księży na rzecz Caritas. W całym 1940 r. regulowało je 88 duchownych $(17,6 \%)$, podczas gdy w sierpniu 1939 r. było to 476 kapłanów $(95,4 \%)$, spadek więc prawie sześciokrotny. Dostępna dokumentacja wskazuje na zorganizowaną akcję składkową dopiero w 1944 r. Objęła ona księży w 29 dekanatach diecezji tarnowskiej. Co istotne, kwota przekazana przez ogół duchowieństwa (323 612 zł) stanowiła ważną pozycję w budżecie Związku, tj. 11\% przychodów

ski, Rozwój detalicznych cen wolnorynkowych w Krakowie w latach w 1939 - 1946, „Rocznik Akademii Handlu w Poznaniu", (1946/1947) s. 184-209; S. Smoliński, Przyczynek do zagadnienia wyżywienia miejskiej ludności polskiej w b. Generalnym Gubernatorstwie na tle ówczesnych warunków pracy i płacy, „Rocznik Akademii Handlowej w Poznaniu”, (1949/1950) s. 33-106.

${ }^{28}$ ADT, Caritas, sygn. Car0 1940, Do rachunku F.Z. 91/40.

${ }^{29}$ ADT, Caritas, sygn. Car0 1940, Do rachunku F.Z. 92/40.

${ }^{30}$ ADT, Caritas, sygn. Car0 1940 Do rachunku F.Z. 109/40; Do rachunku F.Z. 110/40; Do rachunku F.Z. 122/40; Do rachunku F.Z. 144/40. 
w 1944 r. ${ }^{31}$ Przyjmując liczbę księży na parafiach na ok. 500 osób, daje to średnio ok. 650 zł na rok od jednego duchownego. Wysokość datków nie była równomierna w całej diecezji, były takie dekanaty, gdzie środowiska kapłańskie przekazywały kilkanaście czy nawet kilkadziesiąt tysięcy złotych, a inne ledwie po kilka tysięcy złotych (wykres 1).

\section{Wykres 1. Ofiary księży w wybranych dekanatach na Związek Caritas Diecezji Tarnowskiej w 1944 r.}

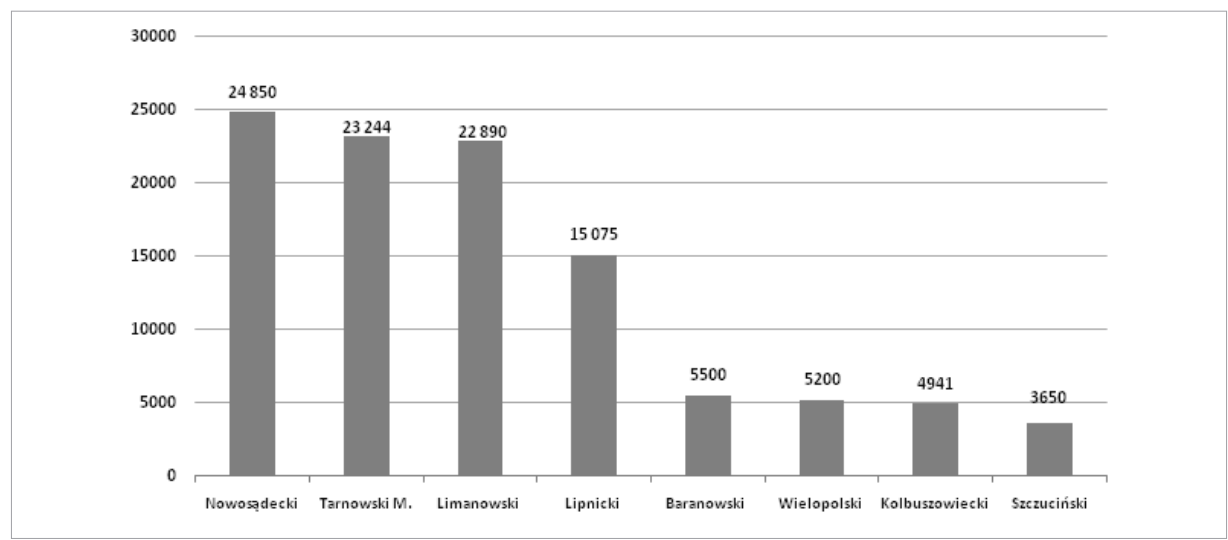

Źródło: ADT, Caritas, sygn. Car0 1944, Sprawozdanie finansowe Związku Caritas Diecezji Tarnowskiẹj za rok 1944. Zestawienie ofiar złożonych przez księży wg dekanạtów.

W tej statystyce dominowały dekanaty, ktore w swoich granicach miały większe ośrodki miejskie bądź jako rozleglejsze terytorialnie obejmowały więcej miejscowości średniej wielkości. A to przekładało się na większą liczbę parafii i posługujących duchownych. Widać to doskonale na przykładzie przodujących dekanatów. Liderem w wysokości składek był dekanat nowosądecki (prawie 25000 zł), tuż zanim tarnowski miejski (ponad 23000 zł) i limanowski z kwotą prawie 23000. Z drugiej strony były środowiska kapłańskie, gdzie wysokość datków z trudem sięgała 5000 zł. W dekanacie szczucińskim i kolbuszowieckim ofiary kleru wynosiły odpowiednio 3650 i 4941 zł, natomiast w wielopolskim - 5200 zł i baranowskim - 5500 zł. Księża z kolejnych 12 dekanatów przekazywali składki zawierające się w kwocie 10 000-15 $000 \mathrm{zt}^{32}$.

Można przyjąć, że księża na Caritas w Tarnowie z osobistych dochodów przekazali 331447 zł. Zdecydowana większość środków była ofiarowana w 1944 r. (wykres 2). Była to kwota imponująca, zwłaszcza na tle innych środowisk kapłańskich w GG. W zasadzie zorganizowaną akcję składkową odnotowano jedynie w diecezji sandomierskiej. Jesienią 1939 r. kilkunastu księży wpłaciło na tamtej-

${ }^{31}$ ADT, Caritas, sygn. Car0 1944, Sprawozdanie finansowe Związku Caritas Diecezji Tarnowskiej za rok 1944. Zestawienie ofiar złożonych przez księży wg dekanatów.

${ }^{32}$ Tamże. 
szy Caritas ok. 45 zł, a wczesną zimą 1944 r. trzech duchownych ofiarowało na cele Związku $550 \mathrm{zł}^{33}$.

\section{Wykres 2. Ofiary księży na Związek Caritas Diecezji Tarnowskiej w latach 1939-1944 r.}

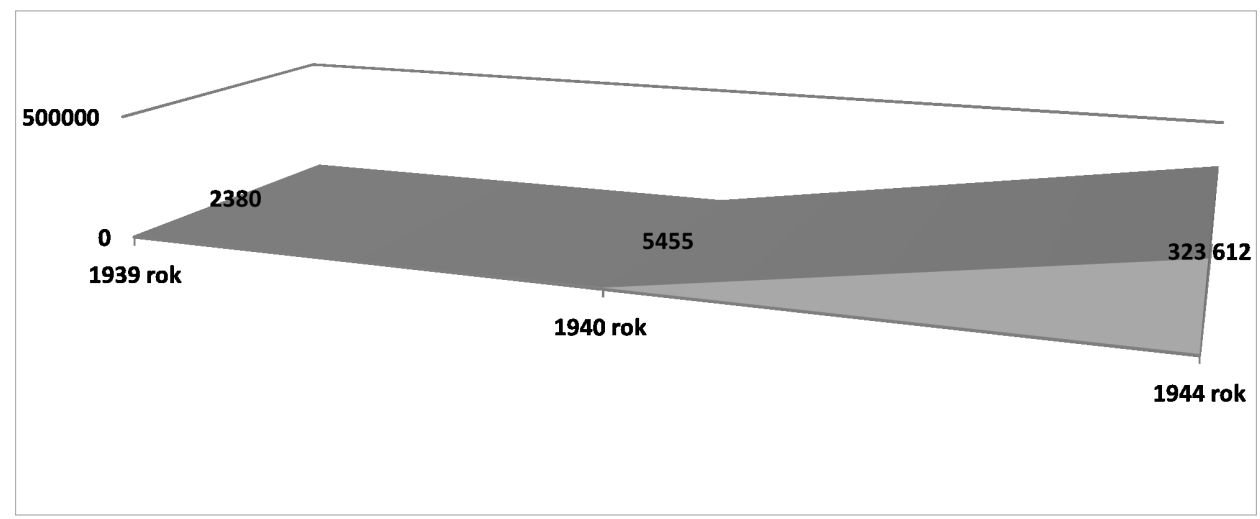

Źródło: ADT, Caritas, sygn. Car0 1941, Do rachunku F.Z. J, sierpień 1939 r.; sygn. Car0 1940, Do rachunku F.Z. 91/40; Do rachunku F.Z. 92/40; Do rachunku F.Z. 109/40; Do rachunku F.Z. 110/40; Do rachunku F.Z. 122/40; Do rachunku F.Z. 144/40; sygn. Car0 1944, Sprawozdanie finansowe Związku Caritas Diecezji Tarnowskiej za rok 1944. Zestawienie ofiar złożonych przez księży wg dekanatów.

\section{Ofiary księży z dochodów prywatnych na rzecz oddziałów parafialnych}

Odziały parafialne, gdzie była prowadzona podstawowa praca opiekuńcza stowarzyszenia, podobnie jak w przypadku centrali, pozyskiwały środki na swoją działalność z rozmaitych źródeł, m.in. subwencji kurii biskupiej, administracji lokalnej, komitetów powiatowych RGO i z ofiar społecznych. Wśród tych ostatnich były datki z osobistych dochodów duchowieństwa. W skali diecezji tarnowskiej nie istniała zorganizowana akcja ofiarności duchowieństwa na rzecz oddziałów ${ }^{34}$, można jedynie mówić raczej o odosobnionych przypadkach ofiarności. Źródła wskazują trzy parafie, w których odnotowano mniej czy bardziej systematyczne wparcie finansowe miejscowych placówek Caritas. W parafii szczepanowskiej były to datki jednorazowe, w bocheńskiej (1944) i chorzelowskiej (19391940) zaś można zaobserwować regularne wielomiesięczne ofiary tamtejszych księży. Ks. Antoni Stańczyk na konto oddziału parafialnego w Chorzelowie przekazał w ciągu 6 miesięcy 150 zł i pościel (wartość 50 zł). Jego postawa jest godna podkreślenia, ponieważ był on jedyną osobą systematycznie wspierającą oddział parafialny Caritas. W tym czasie, np. miejscowe ziemiaństwo, złożyło tylko jed-

${ }^{33}$ Archiwum Diecezji w Sandomierzu (dalej: ADS), Caritas diecezji sandomierskiej 1934-1944 (dalej: Caritas Sandomierz), Caritas, Księga Kasowa 1934-1944; por. Gapys, Działalność charytatywna, s. 141.

${ }^{34}$ Tego zjawiska nie zaobserwowano też w innych diecezjach na terenie GG; Gapys, Działalność charytatywna, s. 142-143. 
norazowe datki: Zofia hr. Tarnowska z Chorzelowa - 12 zł, Szczepan hr. Tarnowski z majątku w Malinie -12 zt $^{35}$.

W parafii bocheńskiej, w skali całej diecezji tarnowskiej, zauważalna jest najbardziej systematyczna akcja ofiarności tamtejszego duchowieństwa. Księża od kwietnia do grudnia 1944 r. ofiarowali 15857 zł, co stanowiło 6,5\% ogólnych przychodów $^{36}$. Wprawdzie kwota przekazana przez kapłanów nie należała do najwyższych, to nietrudno zauważyć, że dużą część przychodów Caritas osiągał z ofiar koordynowanych przez księży, tj. skarbona, tace i okolicznościowe datki przy stoliku. Ogółem z tych źródeł uzyskano ponad 120000 zł. Świadczy to o prowadzeniu przez kapłanów akcji popularyzującej wśród wiernych czynnego chrześcijańskiego miłosierdzia, które wyraziło się w konkretnych kwotach przekazanych przez parafian.

Z kolei w parafii Szczepanów odnotowano wsparcie ze strony księży na początku okupacji, czyli w 1939 r. Tamtejszy oddział Caritasu uzyskał od urzędu parafialnego 70 zł, przy ogólnych przychodach 579 zł. Warto dodać, że większość datków pochodziła z ofiarności parafian: Skarbona św. Antoniego - 375 zł, zbiórki przed kościołem -51 zł. Centrala Caritas w Tarnowie przekazała w formie subwencji 50 zł. Ze składek członkowskich pozyskano jedynie 3 zł $^{37}$.

\section{Ofiary parafialne na rzecz Diecezjalnego Związku Caritas w Tarnowie (centrali)}

Ofiarność księży na potrzeby Caritas w Tarnowie, jak wykazano powyżej, pod koniec wojny przybrała duże rozmiary. Uzupełniały ją przez całą okupację datki wspólnot parafialnych w postaci gotówki (najczęściej tace niedzielne) i zbiórki w naturze. Akcja ofiarności silnie rozwinęła się od 1942 r., głównie na skutek zachęt ze strony biskupa tarnowskiego ${ }^{38}$ i starań centrali Caritas w Tarnowie ${ }^{39}$. Zasadniczą rolę $\mathrm{w}$ realizacji tej akcji w parafii pełnił miejscowy duszpasterz i to na ogół od jego działań zależała skala tego wsparcia. On też przekazy-

${ }^{35}$ ADT, Caritas, CarLC, Wykaz ofiar „Caritas” parafii Chorzelów od 1 września 1939 do dnia 31 grudnia $1940 \mathrm{r}$.

${ }^{36}$ ADT, Caritas, sygn. LB 1 , Zestawienie dochodów Oddziału Caritas w Bochni od 1 IV 1944 1 IV1945; Caritas, Sprawozdanie z działalności Oddziału Caritas przy kościele parafialnym w Bochni za miesiąc listopada 1944. Sprawozdanie kasowe.

${ }^{37}$ ADT, Caritas, sygn. CarLP, Sprawozdanie z działalności Caritasu w Szczepanowicach za okres 1 IX 1939 - 31 XII 1940 r.

${ }^{38}$ ADT, Caritas, sygn. CarO 1944, Pismo kurii tarnowskiej w sprawie świadczeń parafii na rzecz Kościoła, Tarnów1944 r. Akcję ofiarności bp Edward Komar rozwijał kolportując na terenie diecezji Apel abp Sapiehy, por. ADT, Caritas, sygn. Car O 1939, Do Wielebnego Duchowieństwa Archidiecezji Krakowskiej błogosławieństwo i pozdrowienie w Panu, Kraków, 7 X 1939 r.

${ }^{39}$ Centrala każdorazowo dziękowała w stosownym piśmie - podziękowaniu ofiarodawcom, tj. proboszczowi i wiernym. Poza niezbędną kurtuazją (podziękowania dla proboszczów) wskazywano na duchowe skutki dzielenia się swoimi dobrami z potrzebującymi. Kapłanom życzono opieki i błogosławieństwa Bożego, a ofiarodawcom przypominano, że jałmużna wyprasza przez ubogich wiele łask u Boga. Powoływano się na chrześcijańską „Caritas” jako na źródło solidarności z potrzebującymi, ADT, sygn. CarA-CarŻ; sygn. CarO 1942; sygn. CarO 1943; sygn. CarO 1944. 
wał w imieniu parafii datki do Caritasu. Dlatego też pośrednio należy traktować je jako wspólne świadczenia wiernych i duchowieństwa. Środki te w prawie kościelnym traktowano jako oblationes fidelium, o czym była już mowa powyżej ${ }^{40}$.

Dostępna jest regularna i stosunkowo szczegółowa statystyka dla lat 1942$1944^{41}$. Są to zestawienia ogólne, ofiarność według dekanatów, a nawet dane dla poszczególnych parafii. Ze względu na formułę artykułu podjęto się przedstawienia danych ogólnych i dekanalnych. Dostępna statystyka upoważnia do stwierdzenia, że znaczny odsetek parafii na terenie diecezji tarnowskiej przekazywał datki finansowe czy naturalia na rzecz centrali Caritas. W latach 1942-1944, czyli w trzech kolejnych latach budżetowych, do kasy Związku Diecezjalnego Caritas w Tarnowie trafiło łącznie 351445 zł: w gotówce 72114 zł, a do magazynów naturaliów na sumę 279331 zł (wykres 3).

\section{Wykres 3. Ofiarność parafii na rzecz Związku Caritas Diecezji Tarnowskiej 1942-1944}

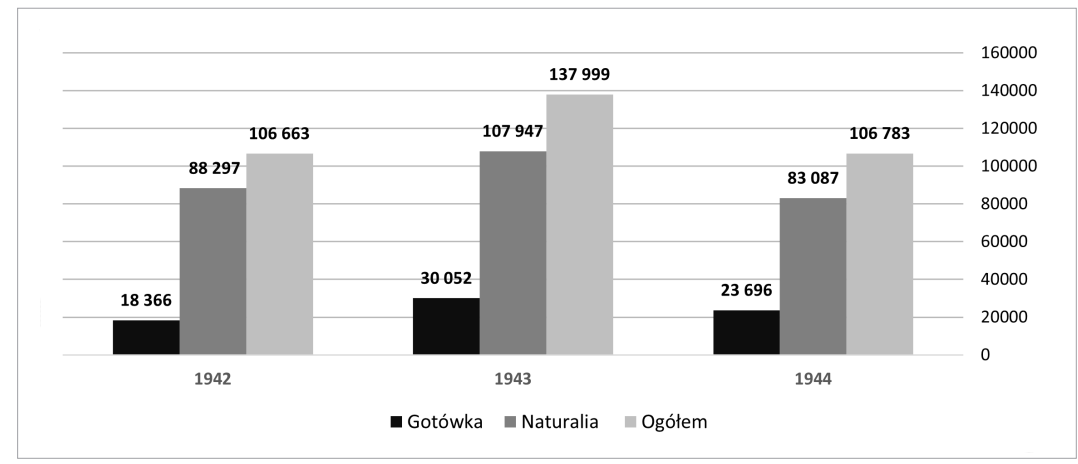

Źródło: ADT, Caritas, sygn. Car0 1942, Rachunek działalności „Caritas” Diecezji Tarnowskiej za rok 1942; sygn. Car0 1942, Rachunek działalności „Caritas” Diecezji Tarnowskiej za rok 1943; sygn. Car0 1944, Sprawozdanie finansowe Związku „Caritas” Diecezji Tarnowskiej za rok 1944. Dochody.

Na przestrzeni trzech lat, jak wynika z wykresu, wysokość datków była silnie zróżnicowana. Najwyższa kwota została przekazana w 1943 r., kiedy to akcja ofiarności była najintensywniejsza. W 1942 r. niższa suma to w dużej mierze rezultat dopiero rozwijającej się akcji, niższe wpłaty w 1944 r. to efekt coraz trudniejszej sytuacji ekonomicznej ludności, która była następstwem wzmożonej eksplo-

${ }^{40}$ ADT, Caritas, sygn. CarO 1944, Pismo kurii tarnowskiej w sprawie świadczeń parafii na rzecz Kościoła, 1944 r.; Gapys, Działalność charytatywna, s. 11-12.

${ }^{41}$ Warto zaznaczyć, że zorganizowaną akcję na rzecz centrali Caritas prowadzono, poza diecezją tarnowską, tylko na terenie archidiecezji krakowskiej. W latach 1942-1943 16 parafii (głównie krakowskich i podkrakowskich) złożyło na tamtejszą centralę kwotę 83746 zł; ANK, Polski Komitet Opiekuńczy w Kraków - miasto 1940-1944 (dalej: Pol.KO Kraków-miasto), sygn. 52, Składki kościelne Oddziałów „Caritas” 1942/1943 (XII 42; I, II, III 1943), k. 747. 
atacji polskiej wsi ${ }^{42}$. Świadczy o tym dobitnie drastyczny spadek przekazywanych naturaliów (o 77\%), z darów na kwotę prawie 108000 zł, do nieco ponad 83000 zł (wykres 3).

Dostępne są również dane dla dwóch lat (1943 i 1944 r.) na poziomie dekanatów. W 1943 r. środki finansowe i naturalia ${ }^{43}$ złożono na terenie 9 dekanatów (31\%) w 29 parafiach (10,2\%), w 1944 r. zaś w 15 dekanatach (52\%), ale tylko w 19 parafiach $(6,7 \%)$, w tym więcej niż połowa (11) znajdowała się w jednym dekanacie - tarnowskim pozamiejskim ${ }^{44}$. Analizując bardziej szczegółowo statystykę dla 1943 r. (wykres 4), można zaobserwować szerszą akcję w trzech dekanatach: dąbrowskim, radłowskim i tuchowskim. Należy mieć tu na uwadze zarówno wysokość datków, jak również liczbę parafii. Zdecydowanym liderem był dekanat tuchowski, w którym ofiarowano na Caritas prawie 10500 zł (9 parafii), mniej niż połowę tej kwoty w dekanacie radłowskim - prawie 4500 (11 parafii) i tarnowskim zamiejscowym - ok. 4000 (12 parafii), w dąbrowskim pięciokrotnie mniej - nieco ponad 2000 (16 parafii). W pozostałych pięciu kwoty wahały się na niskim poziomie od $100 \mathrm{zł} \mathrm{w}$ radomyskim (6 parafii) do $620 \mathrm{zł} \mathrm{w}$ wojnickim (9 parafii).

${ }^{42} \mathrm{~W}$ diecezji tarnowskiej dominowała ludność wiejska, stąd w ofiarności przeważały naturalia. Drastyczny spadek datków naturze zaobserwowany w 1944 r. to w dużej mierze efekt wzrostu obciążeń kontyngentowych od 1943 r., AAN, Delegatura Rządu na Kraj 1940-1944 (dalej: Delegatura), sygn. 202/III.13, k. 12-13; AK, sygn. 203/X-67, k. 9, Centrale Archiwum Wojskowe Warszawa Rembertów (dalej: CAW), VI Oddział Sztabu, sygn. 1777/90/482, k. 32; sygn. 1777/90/478, k. 18; sygn. 1777/90/476, k. 43; Okupacja i ruch oporu w Dzienniku Hansa Franka 1939-1945, red. Cz. Madajczyk, t. 1: 1939-1945, Warszawa 1972, s. 540.

${ }^{43}$ Dla 1943 r. podano ilość złożonych naturaliów w kg, dlatego też nie ma tych danych ma na wykresie, dla 1944 r. zaś w statystyce zamieszczono wartość w złotych przekazanej żywności.

${ }^{44}$ ADT, Caritas, sygn. Car0 1942, Rachunek działalności „Caritas” Diecezji Tarnowskiej za rok 1943; sygn. Car0 1944, Sprawozdanie finansowe Związku Caritas Diecezji Tarnowskiej za rok 1944. 


\section{Wykres 4. Wysokość składek finansowych z parafii wg dekanatów na rzecz Związku Caritas Diecezji Tarnowskiej 1943 r.}

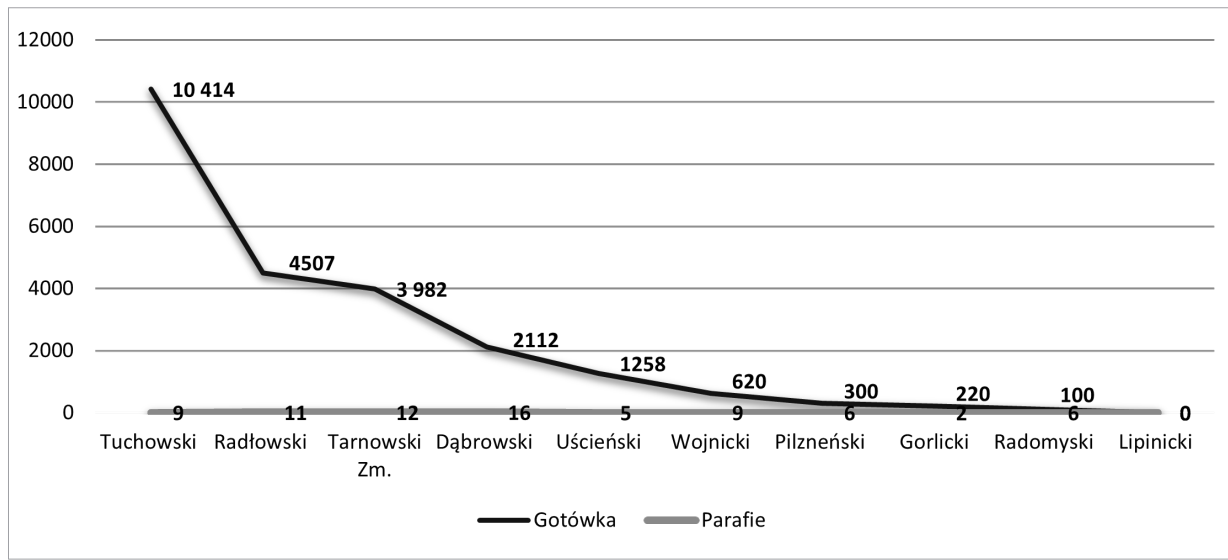

Źródło: ADT, Caritas, sygn. Car0 1942, Rachunek działalności Związku Caritas Diecezji Tarnowskiej za rok 1943. Ofiary parafii wg dekanatów.

Odnosząc się do szczegółowego zestawienia datków za 1944 r. (gotówka i naturalia), można zauważyć, że na czele darczyńców były znów te same dekanaty: dąbrowski, tuchowski i radłowski (wykres 5). Dekanat dąbrowski złożył $18500 \mathrm{zł,}$ tuchowski prawie 15 000, radłowski zaś blisko $10000 \mathrm{zł}$.

\section{Wykres 5. Wysokość składek finansowych i naturaliów parafii wg dekanatów na rzecz Związku Caritas Diecezji Tarnowskiej 1944 r.}

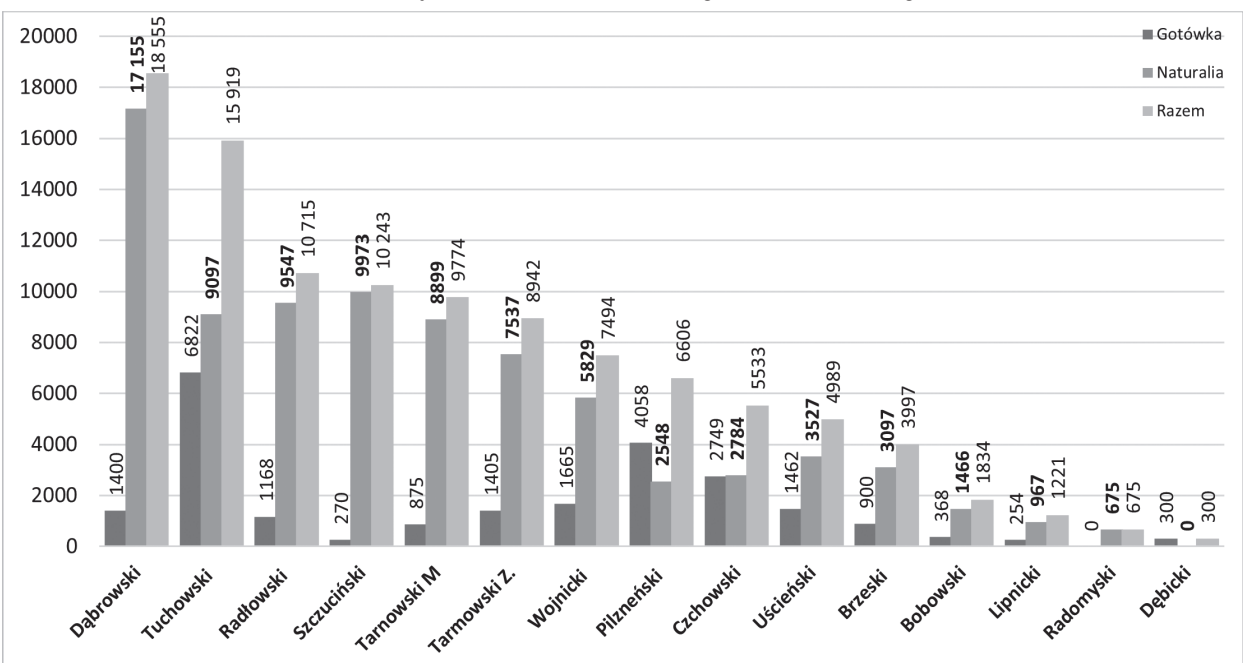

Źródło: ADT, Caritas, sygn. Car0 1944, Sprawozdanie finansowe Związku Caritas Diecezji Tarnowskiej za rok 1944. Zestawienie ofiar złożonych przez parafie - dekanatami. 
W ofiarach gotówkowych zdecydowanie przewodził dekanat tuchowski $6822 \mathrm{zł}$ (naturalia - 9097 zł), w naturaliach zaś dąbrowski - 17155 zł (w gotówce tylko 1409 zł). Poza dekanatami szczucińskim i tarnowskimi (miejski i zamiejscowy) ofiary w pozostałych nie sięgały połowy wysokości tych najlepszych, a w 6 dekanatach kwoty nie przekraczały 5000 (ok. 25\% kwoty najwyższej), w dwóch najsłabszych datki wynosiły od 300 (dębicki) do 675 zł (radomyski). Podsumowując dane $\mathrm{z}$ dwóch lat, można zaobserwować silniejszą akcję w większych i liczniejszych dekanatach diecezji położonych w centralnej części diecezji, większość z dekanatów zaś, w których w ogóle odnotowano zjawisko ofiarności, leżała w pasie centralnym i zachodnim.

Osobnym zagadnieniem było wsparcie udzielane przez kurię tarnowską Diecezjalnemu Związkowi Caritas w Tarnowie ${ }^{45}$. W latach 1942-1944 przekazała ona na rzecz Związku 2472000 zł. Zestawiając świadczenia kurii z subwencją komitetu opiekuńczego w Tarnowie i ofiarami społecznymi, da się zauważyć, że poza 1942 r. wysokość środków kurialnych była wyższa o 40-60\% od ofiar społecznych, a od dotacji komitetu nawet 29-krotnie. Szczególnie imponujący jest wzrost subwencji w 1943 r., kwota wzrosła niemal 9-krotnie, a w następnym roku ponad 2-krotnie w stosunku do 1943 r. (wykres 6).

${ }^{45}$ Datki kurii czy biskupa ordynariusza w skali GG poza diecezją tarnowską zaobserwowano jedynie w diecezji kieleckiej. W 1942 r. ks. bp Czesław Kaczmarek przekazał na kuchnie tamtejszego Caritasu naturaliów na kwotę 40 tys. zł po kursie wolnorynkowym (4000 zł po oficjalnym kursie); AAN, RGO 1939-1945, sygn. 321, k. 14; sygn. 482, k. 2, 5, 46-50, 130-131, 157, 161, 196-198; sygn. 483, k. 16; sygn. 524, k. 99-100; sygn. 758, k. 1, 22; sygn. 1933, k. 56; Archiwum Diecezji Kieleckiej (dalej: ADK) Akta Kurialne Ogólne (dalej: AKO), sygn. OE-3/1, k. 83; tamże, sygn. OE-2/4, Notatnik charytatywny ks. Stanisława Borowieckiego, k. 1-40; sygn. OE-2/2, k. 90. 
Wykres 6. Subwencje kurii tarnowskiej na Caritas Diecezji Tarnowskiej w latach 1942-1944

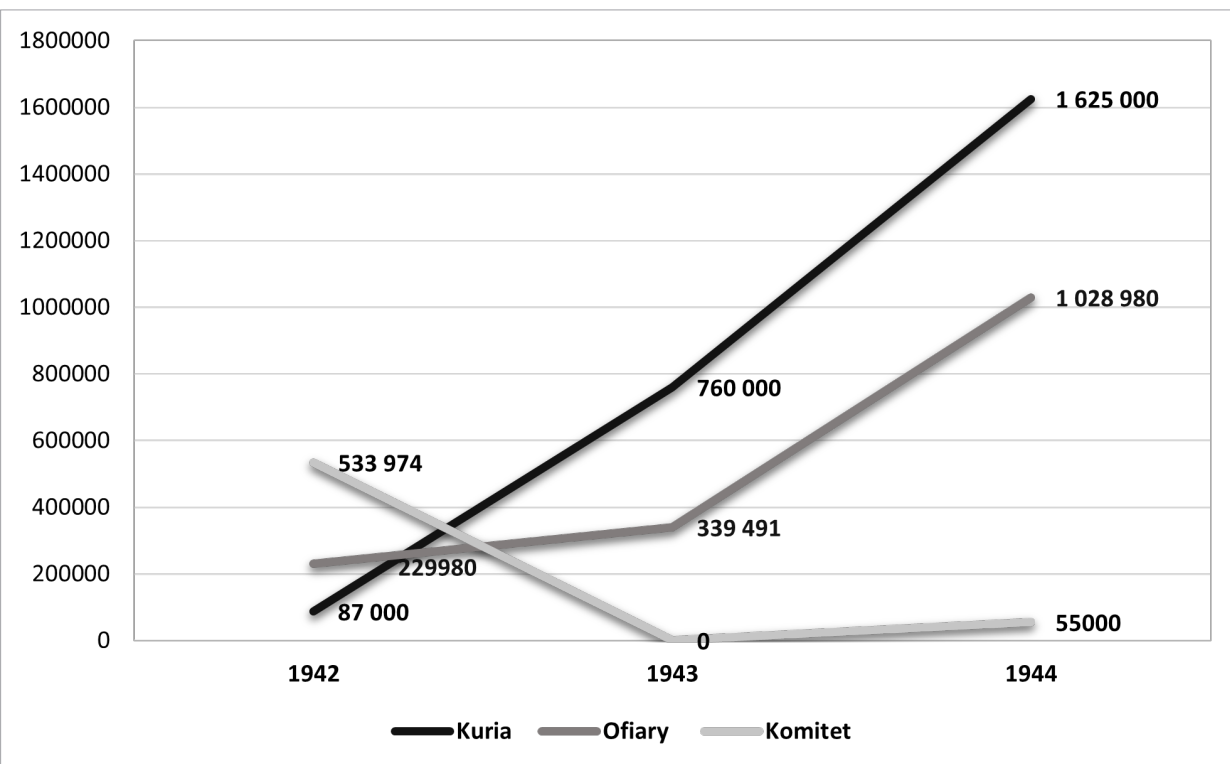

Źródło: ADT, Caritas, sygn. Car0 1942, Zestawienie bilansowe działalności Caritas za dzień 31 grudnia 1942 r. dochody budżetowe, sygn. Car0 1942, Rachunek działalności Związku „Caritas” Diecezji Tarnowskiej za rok 1943 r.; sygn. Car0 1944, Sprawozdanie finansowe Związku Caritas” Diecezji Tarnowskiej za rok 1944.

Interesująco rozkładała się wysokość subwencji w okresie roku kalendarzowego, jako przykład można wskazać 1943 r. (wykres 7). Najwyższe wpłaty miały miejsce w miesiącach letnich: lipiec-sierpień (150 000 i 115 000), stosunkowo wysokie w październiku i grudniu (po 100 000), najniższe zaś we wrześniu i listopadzie (po 20 000), absolutne zaś minimum w styczniu - $3000 \mathrm{zł}$.

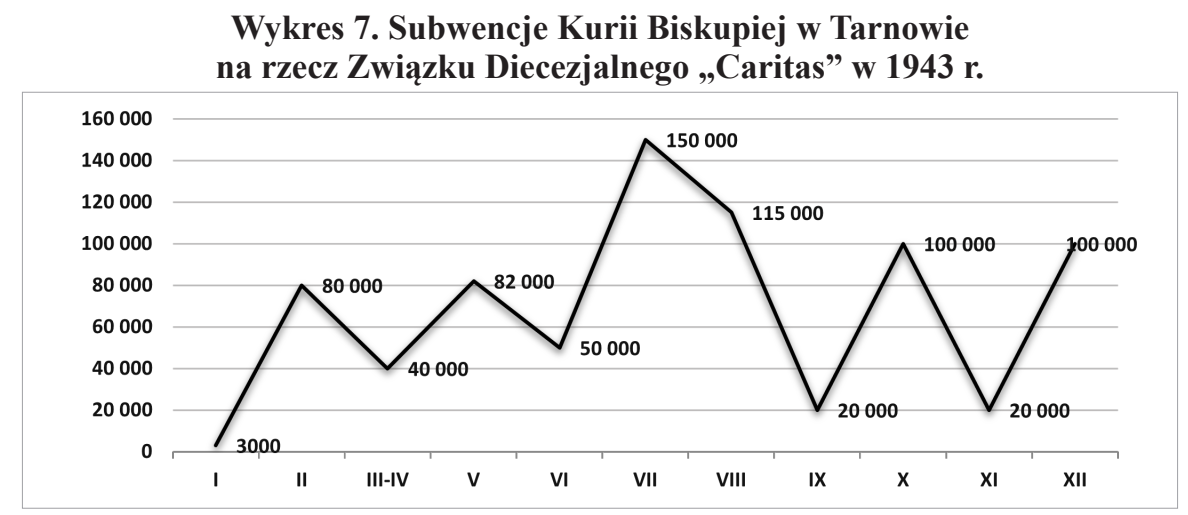

Źródło: ADT, Car0 1942, Rachunek działalności Związku „Caritas” Diecezji Tarnowskiej za $1943 \mathrm{r}$. 
Podsumowując wysokość ofiar, datków i subwencji przekazanych przez kapłanów, wspólnoty parafialne i kurię tarnowską, uzyskuje się wartość 315492 zł, stanowiło to aż 58,9\% ogólnych przychodów Caritas w latach 1942-1944 (5 356239 zł). Była to kwota bardzo wysoka ${ }^{46}$, choćby w zestawieniu z ofiarami miejscowego ziemiaństwa - w tym czasie przekazało ono ok. 16500 zł (0,3\%). Struktura ofiarności duchoweństwa i wspólnot parafialanych wskazuje jednoznacznie, że ponad 3/4 Środków przekazanych stowarzyszeniu pochodziło z kurii (78,4\%), datki parafialne - 11,1\%, a składki osobiste księży stanowły 10,5\% (wykres 8).

\section{Wykres 8. Struktura ofiarności duchowieństwa na Związek Diecezjalny Caritas w Tarnowie w latach 1942-1944}

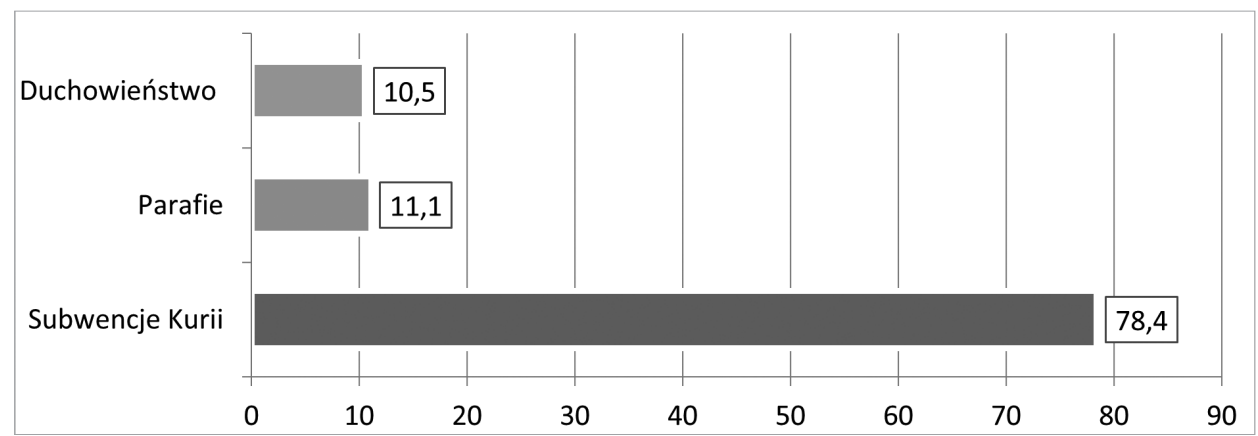

Źródło: ADT, Caritas, sygn. Car0 1942, Rachunek działalności „Caritas” Diecezji Tarnowskiej za rok 1943; sygn. Car0 1944, Sprawozdanie finansowe Związku „Caritas” Diecezji Tarnowskiej za rok 1944. Dochody; sygn. Car0 1942, Zestawienie bilansowe działalności Caritas za dzień 31 grudnia 1942 r. dochody budżetowe; sygn. Car0 1942, Rachunek działalności Związku „Caritas” Diecezji Tarnowskiej za rok 1943 r.; sygn. Car0 1944, Sprawozdanie finansowe Związku „Caritas” Diecezji Tarnowskiej za rok 1944.

Tak ogromna różnica na korzyść kuri tarnowskiej była następstwem działań kurii (po śmierci bp E. Komara diecezją zarządał wikariusz kapitulny ks. prałat Stanisław Bulanda), która mimo okupacji prowadziła skuteczną politykę finansową nakierowaną na pomoc społeczną wobec braku własnego państwa. Wyraźnie pisano o tym w piśmie wyjaśniającym direcotium z 1944 r.:

Składki tego rodzaju jak świętopietrze, na misje katolickie Ziemię Świętą muszą być podtrzymane ze względów zasadniczych; tego wymagają zarządzenia Stolicy Apostolskiej, życie wewnęrzne Kościoła św. i wzgląd religijno-wychowawczy. Do podtrzymania zaś obowiązku odsyłania składek na kościoły filialne, potrzeby ogólnodiecezjalne i seminaria (I niedziela miesiąca) - zmusza samo życie diececji w obecnych warunkach. Skoro bowiem państwo nie pomaga, jak w czasach przedwojennych swymi dotacjami na seminarum, utrzy-

${ }^{46} \mathrm{~W}$ skali GG diecezja tarnowska była zdecydowanym liderem. Jedynie kręgi kościelne w archidiecezji krakowskiej przekazały na rzecz Caritasu stosunkowo wysokie sumy w 16 parafiach krakowskich i podkrakowskich - 83746 zł; Gapys, Działalność charytatywna, s. 144. 
manie PT, Kapituły, Profesorów Semianarium Duchownego i administracji diecezji - to wierni muszą się przyczynić do zaspokojenia tych istotnych potrzeb diecezji (...) Składkę na Caritas (III niedziela miesiąca) wywołały i każą podtrzymac te nadzywczajne czasy i potrzeby spowodowane wypadkami wojennymi, na które patrzymy. Opieka nad ubogimi, opuszczonymi i dotkniętymi nieszczęściem należy do istoty życia Kościoła św. i posłannictwa kapłanów. Nadzwyczajne czasy nakładają nadzwyczajne obowiązki, które choćby wydawały by się i ciężkemi, jednak spełnianie być muszą, jeśli chcemy mieć sumienie spokojne, że spełniliśmy przyjęty na siebie obowiązek i posłannictwo Chrystusowe ${ }^{47}$.

\section{Ofiarność księży i datki kościelne na oddziały parafialne Caritas}

W odniesieniu do zakrojonej na znaczną skalę akcji ofiarności duchowieństwa i środowisk parafialnych na centralę Caritas (choć jak wykazano zróżnicowanej w czasie i nierównomiernie rozłożonej terytorialnie) wsparcie dla oddziałów parafialnych nie przybrało charakteru powszechnego, można raczej mówić o wyizolowanych parafiach na terenie diecezji tarnowskiej ${ }^{48}$. Jedynie w kilku z nich można wskazać na w miarę systematyczne, a niekiedy i długofalowe wsparcie miejscowych oddziałów parafialnych. Jedną z nich była parafia w Piwnicznej. Przez cały okres okupacji tamtejszy proboszcz organizował zbiórki kościelne lub wystawiał puszki (Puszka św. Antoniego) na rzecz Caritasu. W latach 1939-1944 zbiórki kościelne wyniosły 13951 zł, przy ogólnych przychodach w kwocie 19592 zł było to aż 71\% ogółu. W 1943 r. składki kościelne stanowiły nawet 74\% wszystkich przychodów. Najwyższa kwota została przekazana oddziałowi w 1944 r. 8811 zł, najniższa w 1939 r. - 85 zł. Obok ofiar kościelnych Caritas pozyskiwał środki ze składek członkowskich, które stanowiły drugie co do wysokości źródło dochodów (26-29 członków). Oddział incydentalnie otrzymywał też subwencje z kurii, centrali Caritas bądź od miejscowej delegatury RGO, były to jednak kwoty, które nie miały decydującego wpływu na wysokość budżetu. Należy więc zauważyć, że działalność opiekuńcza oddziału opierała się na ofiarności parafii, czyli na samodzielności finansowej jednostki opiekuńczej, co było celem każdego oddziału $^{49}$.

Systematyczne i relatywnie wysokie datki ze strony Kościoła odnotowano też w parafii katedralnej w Tarnowie. Dobrze to egzemplifikują przychody tamtejszego oddziału Caritasu od 1 września 1939 do 15 lutego 1943 r. Parafia katedralna

\footnotetext{
${ }^{47}$ ADT, Caritas, sygn. Car0 1944, Pismo wyjaśniające do Directorium z 1944 r. do księży diecezji tarnowskiej, Tarnów 1944.

${ }^{48}$ Zresztą nie tylko w badanej diecezji, ale również na terenie GG brak jest zorganizowanej akcji w tym zakresie czy nawet w ogóle żadnej aktywności; por. Gapys, Działalność charytatywna, s. 141-142.

${ }^{49}$ ADT, Caritas, sygn. CarLP, Sprawozdanie z działalności Caritasu w Piwnicznej za okres 1 IX 1939-31 XII 1940 r.; sygn. CarLP, Sprawozdanie z działalności Caritasu w Piwnicznej za 1941 r.; sygn. CarLP, Sprawozdanie z działalności Caritasu w Piwnicznej za 1942 r.; sygn. CarLP, Sprawozdanie z działalności Caritasu w Piwnicznej za 1943 r.; sygn. CarLP, Sprawozdanie z działalności Caritasu w Piwnicznej za 1944 r.
} 
przekazała w tym okresie na cele społeczne 5246 zł, centrala Caritas 8693 zł, kuria biskupia 1000 zł, kapłani 144 zł, subwencja z miejscowego komitetu opiekuńczego zaś sięgnęła ponad 110000 zł (wykres 9).

\section{Wykres 9. Ofiary kościelne kurii tarnowskiej, centrali Caritas, parafii katedralnej i księży na rzecz oddziału parafialnego w kościele katedralnym w Tarnowie 1939-1943}

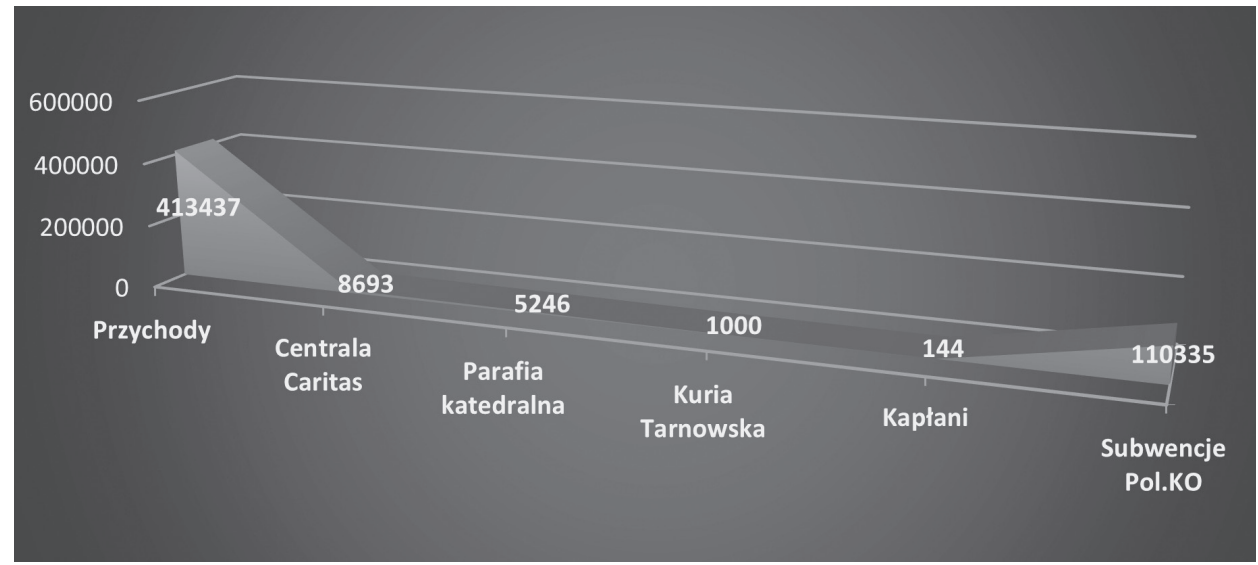

Źródło: ADT, Caritas, sygn. Car LT 1 , Sprawozdanie kasowe oddziału „Caritas” parafii katedralnej w Tarnowie za czas od 1IX 1940 - 28 II 1941 r.; ADT, Caritas, sygn. CarLT, Sprawozdanie w cyfrach z działalności Caritas przy Katedrze za czas 1 IX 1939 - 31 VIII 1940 r.; sygn. LT 3 , Zestawienie wpływów i wydatków Oddziału Caritas Parafii Katedralnej - Skontrum, 15 II 1943 r.

Ogółem w parafii środowiska kościelne ofiarowały na dzieło miłosierdzia prowadzone przez oddział katedralny Caritas w Tarnowie 15083 zł, co stanowiło $3,6 \%$ wszystkich przychodów w latach 1939-1943. Jest to niewielki odsetek w porównaniu choćby z wyżej opisanym oddziałem w Piwnicznej (ponad 70\%) czy też datkami kościelnym złożonymi na centralę Caritas, które stanowiły ponad 58\% ogółu przychodów Związku.

W kilku parafiach miała miejsce zorganizowana akcja ofiarności w początkowych latach okupacji. Na ogół datki kościelne stanowiły podstawowe źródło dochodów oddziałów Caritas. W parafii Porąbka Uszewska od 1 września 1939 do końca 1940 r. wierni złożyli na Związek 801 zł, co stanowiło 68,3\% ogólnych przychodów $^{50}$. W parafii Szczepanów w 1939 r. kapłani złożyli 70 zł, zbiórki przed kościołem i Puszka św. Antoniego dały 426 zł, centrala Caritas przekazała zaś 50 zł. Ogółem więc ofiary kościelne wyniosły 496 zł, stanowiło to 85,6\% przychodó $^{51}$. W Trzcianie w 1940 r. tamtejszy oddział parafialny pozyskał ze składek kościelnych (Puszka św. Antoniego) i z ofiar dzieci pierwszokomunijnych jedynie $78 \mathrm{zl}$, ale przy skromnych przychodach wpływy te wyniosły $44,8 \%$ bu-

${ }^{50}$ ADT, Caritas, sygn. CarLP, Sprawozdanie z działalności Caritasu w Porąbce Uszewskiej za okres 1 IX 1939 - 31 XII 1940 r.

${ }^{51}$ ADT, Caritas, sygn. CarLP, Sprawozdanie z działalności Caritasu w Szczepanowicach za okres 1 IX 1939 - 31 XII 1940 r. 
dżetu $^{52}$. Z kolei w parafii Gwoździce, kontynuując wieloletnią tradycję, zorganizowano jesienią $1940 \mathrm{r}$. V Tydzień Miłosierdzia, który zaowocował datkami w wysokości: dar ołtarza 1445 zł i taca kościelna 1105 zł. Brak jest w źródle danych odnośnie do innych źródeł finansowania Caritasu ${ }^{53}$.

Dostępne są także informacje o składkach Księży Misjonarzy w parafii Św. Rodziny w Tarnowie. W $1941 \mathrm{r}$. misjonarze przekazali oddziałowi $680 \mathrm{zł}$, środki te stanowiły $15 \%$ przychodów placówki charytatywnej. Podstawowe fundusze na działalność pochodziły z komitetu opiekuńczego - w $1941 \mathrm{r}$. subwencja wyniosła $3000 \mathrm{zł}(67,2 \%)^{54}$.

O niecodziennej (aczkolwiek praktykowanej w okresie wojny też przez inne organizacje dobroczynne $)^{55}$ formie wsparcia, czyli pomocy bezpośredniej, można przeczytać w sprawozdaniu charytatywnym z parafii Biegonice. Ksiądz pisał w taki sposób o swoich działaniach charytatywnych:

Jeśli chodzi o urząd parafialny, to w zbożnej tej robocie stara się nie pozostawać daleko w tyle poza innymi. Plebania jest w ciągłym kontakcie z całą parafią i wie o wszystkim, co zresztą jest możliwe przy jej małości. Kilkanaście rodzin znajduje stałe oparcie o plebanię, plebania służy chętnie potrzebującym konną robocizną, opałem, opieką pół-lekarską itd. W pierwszych latach wojny plebania odebrawszy wprzód dzierżawiony grunt rolny bogatszym przydzieliła kilkunastu najbiedniejszym parafianom po kawałku roli, w ogólnej ilości 10 ha, bez względu na jakiekolwiek wynagrodzenie ${ }^{56}$.

Na koniec warto przyjrzeć się solidaryzmowi w ramach struktur diecezjalnych Caritas. Pozyskiwane przez centralę Związku środki od księży, wiernych, ofiar społecznych, subwencji kurii, władz lokalnych i RGO podlegały redystrybucji z powrotem do oddziałów, głównie do tych o zwiększonych potrzebach ${ }^{57}$. W 1942 r. Związek przekazał subwencje do 51 oddziałów na kwotę 27700 zł i do trzech parafii naturalia o wartości 1069 zł (Czchów, Filipowice, Tarnów-Katedra) - razem 28769 zł. Na ogół były to środki w wysokości 300-500 zł na parafię, ale niektóre oddziały Caritas (Czchów, Janowice, Kolbuszowa, Krynica i parafia XX Misjonarzy w Tarnowie) otrzymały subwencje po $1000 \mathrm{zł}$, a parafia katedral-

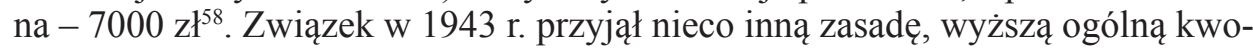

${ }^{52}$ ADT, Caritas, sygn. CarLT ${ }_{4}$, Sprawozdanie z działalności Caritas za rok 1940 na terenie parafii Trzciana.

${ }^{53}$ ADT, Caritas, sygn. CarLG ${ }_{2}-$ CarI - CarLJ, Sprawozdanie z V Tygodnia Miłosierdzia z parafii Gwoździce 12.11.1940 r.

${ }^{54}$ ADT, Caritas, sygn. CarLT ${ }_{4}$, Sprawozdanie kasowe Caritas parafii Św. Rodziny w Tarnowie od 1.II-31.III.1941 r.

${ }^{55}$ Zjawisko bezpośredniej pomocy funkcjonowało np. w działalności Delegatur Rady Głównej Opiekuńczej, zob. na temat form opieki w RGO; por. Kroll, Rada Główna Opiekuńcza; s. 163-179.

${ }^{56}$ ADT, Caritas, sygn. CarLN, Sprawozdanie z akcji charytatywnej w parafii Biegonice, Biegonice 31.05.1944 r. Silna pomoc bezpośrednia w parafiach, nawet bez istnienia oddziału Caritas funkcjonowała całkiem szeroko w diecezji kieleckiej i sandomierskiej; por. Gapys, Działalność charytatywna; s. 88-90.

${ }^{57}$ Poza diecezją tarnowską takiego zjawiska nie zaobserwowano.

${ }^{58}$ ADT, Caritas, sygn. Car0 1942, Sprawozdanie Związki Caritas Diecezji Tarnowskiej za rok 1942. Wyszczególnienie oddziałów, które otrzymały subwencje z Centrali w Tarnowie. 
tę przeznaczył na subwencje dla mniejszej liczby parafii. Środki finansowe otrzymały 23 parafie (ogółem 42997 zł) i 6 parafii datki w naturaliach - 4601 zł. Subwencje gotówkowe na ogół wynosiły 1000 zł. Niekiedy kilkukrotnie wyższe kwoty otrzymały oddziały parafialne, które prowadziły z reguły dużą akcję pomocową lub ze względu na lokalne uwarunkowania wymagały wsparcia (bezrobocie, wysoki odsetek bezrolnych i małorolnych, niski poziom ofiarności społeczności lokalnej). Oddział parafii katedralnej w Tarnowie na swoją wieloraką działalność otrzymał z centrali 11801 zł, Krynica - 4000 zł, Nowy Sącz - 3000 zł ${ }^{59}$.

Podsumowując przeprowadzoną analizę ofiarności kręgów kościelnych (kuria, księża, parafie/wierni), da się zauważyć, że początek okupacji przyniósł destabilizację w akcji ofiarności na rzecz centrali Caritas. Widoczne to było we wszystkich środowiskach ofiarodawców. W kręgach kapłańskich przejawiło się to przede wszystkim spadkiem liczby ofiarodawców (z prawie 500 księży do 88) i systematyczności datków. Dopiero w 1944 r. grono ofiarodawców znów osiągnęło liczbę ok. 480 księży. Ogółem w latach 1939-1944 kapłani przekazali ponad 330000 zł. Natomiast wsparcie duchownych wobec oddziałów przybrało charakter wyizolowanych parafii, w części z nich datki księży wraz z ofiarami wiernych stanowiły ponad $2 / 3$ a nawet $3 / 4$ ogólnych dochodów. Podobnie i w parafiach apogeum akcji ofiarności odnotowano w końcowych latach okupacji: w 1943 i 1944 r. Wówczas zjawisko przekazywania datków zaobserwowano w 1943 r. w 31\% dekanatach, a 1944 r. w 52\% oraz odpowiednio $29(10,2 \%)$ i 19 parafiach $(6,7 \%)$. Ogółem wierni poprzez kapłanów przekazali $351445 \mathrm{zł}$ na Caritas w Tarnowie. Inspirowana przez duszpasterzy ofiarność wiernych na rzecz oddziałów nie przyjęła charakteru masowej akcji, jedynie w kilku parafiach przybrała ona postać bardziej systematyczną, niekiedy datki te były podstawą budżetu oddziału. Ze względu na politykę finansową bp. E. Komara na czas wojny i okupacji Kuria Tarnowska była największym ofiarodawcą na rzecz Związku - 2472000 zł. Stanowiło to prawie $60 \%$ ogółu przychodów Caritasu tarnowskiego w dobie okupacji, ponad 78\% zaś wszystkich ofiar ze strony Kościoła na stowarzyszenie.

\section{REFERENCES / BIBLIOGRAFIA}

\section{Źródla archiwalne}

Archiwum Akt Nowych w Warszawie Rada Główna Opiekuńcza 1939-1945. Delegatura Rządu na Kraj 1939-1944. Armia Krajowa 1939-1945.

Archiwum Diecezjalne w Siedlcach Caritas, t. 3, 1931-1948.

${ }^{59}$ ADT, Caritas, sygn. Car0 1942, Rachunek działalności Związku Caritas Diecezji Tarnowskiej za rok 1943. Świadczenia bezpośrednie na akcję charytatywną w parafiach. 
Archiwum Diecezjalne w Tarnowie

Caritas 1947-1950.

Archiwum Kurii Metropolitarnej w Krakowie

Teki Sapieżyńskie, TS XXVII/26, Ogólnopolski Zjazd Dyrektorów Diecezjalnych Związków „Caritas” w Poznaniu 23 II 1937.

Archiwum Narodowe w Krakowie

Polski Komitet Opiekuńczy w Kraków - miasto 1940-1944.

Związek Stowarzyszeń i Zakładów Dobroczynnych, Wychowawczych i Opiekuńczych Archidiecezji Krakowskiej „Caritas” z lat 1934-1940.

Centralne Archiwum Wojskowe Warszawa - Rembertów

VI Oddział Sztabu.

\section{Źródła drukowane}

Caritas. Miłosierdzie Chrześcijańskie w parafii. Katolickie Towarzystwo Dobroczynności Diecezji Płockiej „,Caritas”, Płock 1935.

Rocznik diecezji tarnowskiej na rok 1942, Tarnów 1942.

Rocznik diecezji tarnowskiej na rok 1943, Tarnów 1943.

Rocznik diecezji tarnowskiej na rok 1944, Tarnów 1944.

\section{Opracowania}

Aleksandrowicz Piotr, Diecezja siedlecka czyli podlaska $w 150$ rocznice erekcji (18181968). Przyczynki i materiały do dziejów Diecezji Siedleckiej czyli Podlaskiej, Siedlce 1971.

Dzieje diecezji tarnowskiej Instytucje $i$ wydarzenia, t. 2: Instytucje $i$ wydarzenia, red. A. Gąsior, J. Królikowski, Tarnów 2012.

Fijałkowski Zenon, Kościół katolicki na ziemiach polskich $w$ latach okupacji hitlerowskiej, Warszawa 1983.

Gapys Jerzy, „Caritas” w diecezji kieleckiej w latach II wojny światowej, w: Dobroczynność i pomoc spoleczna na ziemiach polskich $w$ XIX $i$ XX i na początku XXI wieku, t. 2, red. M. i M. Przeniosło, Kielce 2010, s. 173-189.

Gapys Jerzy, Działalność charytatywna duchowieństwa diecezjalnego w Generalnym Gubernatorstwie 1939-1945, Kielce 2012.

Gretkowski Andrzej, Katolicyzm społeczny na przykładzie działalności charytatywno-społecznej w diecezji płockiej w I połowie XX wieku, Płock 2001.

Historia katolicyzmu społecznego w Polsce 1832-1939, red. Cz. Strzeszewski, R. Bender, K. Turowski, Warszawa 1981.

Kępski Czesław, Idea miłosierdzia a dobroczynność i opieka, Lublin 2002.

Kroll Bogdan, Rada Gtówna Opiekuńcza 1939-1945, Warszawa 1985.

Kumor Bolesław, Diecezja Tarnowska i jej stan w 1939 r. Zarząd i organizacja diecezji. Duchowieństwo 1939-1945, w: Życie religijne w Polsce pod okupacja hitlerowska 1939-1945, red. Z. Zieliński, Warszawa 1982, s. 253-267.

Kumor Bolesław, Historia Kościoła, cz. 8: Czasy współczesne 1914-1992. Kościół katolicki w okresie systemów totalitarnych i odnowy soborowej, zniewolenie Kościołów wschodnich, sekularyzacja i rozdrobnienie Kościołów i wspólnot protestanckich, Lublin 1995. 
Kurlenda Piotr, Działalność dobroczynna Kościoła katolickiego w Wielkopolsce i na Pomorzu w latach 1919-1939, Toruń 2001.

Leś Ewa, Od filantropii do pomocniczości. Studium porównawcze rozwoju i działalności organizacji społecznych, Warszawa 2000.

Madajczyk Czesław, Generalna Gubernia w planach hitlerowskich. Studia, Warszawa 1961.

Majka Józef, Chrześcijańska myśl i ruch charytatywny, w: Historia katolicyzmu społecznego w Polsce 1832-1939, red. Cz. Strzeszewski, R. Bender, K. Turowski, Warszawa 1981, s. 257-329.

Majka Józef, Kościelna działalność dobroczynna w Polsce w XIX i pierwszej połowie XX wieku, ,Zeszyty Naukowe KUL”, 9 (1966) nr 1-2, s. 117-137.

Podgórski Marek, Powstanie i pierwsze lata działalności Caritas diecezji tarnowskiej, w: Misericors - 75 lat działalności Caritas diecezji tarnowskiej, red. P. Grzanka, Tarnów 2012, s. 271-281.

Podstołowicz Ryszard, Grzanka Piotr, Wczoraj i dziś Caritas diecezji tarnowskiej, w: Misericors - 75 lat działalności Caritas diecezji tarnowskiej, red. P. Grzanka, Tarnów 2012.

Smoliński Stanisław, Rozwój detalicznych cen wolnorynkowych $w$ Krakowie $w$ latach w 1939-1946, „Rocznik Akademii Handlu w Poznaniu”, (1946/1947) s. 184-209.

Smoliński Stanisław, Przyczynek do zagadnienia wyżywienia miejskiej ludności polskiej w b. Generalnym Gubernatorstwie na tle ówczesnych warunków pracy i płacy, „Rocznik Akademii Handlowej w Poznaniu", (1949/1950) s. 33-106.

Sugier Edward, Odpowiedzialność Kościoła za ubogich i chorych w świetle kościelnego prawodawstwa partykularnego w Polsce międzywojennej, Koszalin 2001.

Wilk Stanisław, Episkopat Kościoła katolickiego w Polsce w latach 1918-1939, Warszawa 1992.

Wójcik Walenty, Ze studiów nad synodami polskimi, Lublin 1982.

Wójtowicz S., Zwiazek „Caritas” Diecezji Tarnowskiej w stużbie bliźnim w latach 19391950, w: Dzieje diecezji tarnowskiej Instytucje $i$ wydarzenia, t. 2, red. A. Gąsior, J. Królikowski, Tarnów 2012.

Życie religijne w Polsce pod okupacją hitlerowska 1939-1945, red. Z. Zieliński, Warszawa 1982. 


\title{
GENEROSITY OF THE CLERGY AND CHURCH (PAROCHIAL) CONTRIBUTIONS TO THE CARITAS ASSOCIATION OF THE TARNÓW DIOCESE OVER THE YEARS 1939-1945
}

\begin{abstract}
After the initial destabilization of the Church's charitable actions in the Tarnów diocese (subsidies from the curia, personal donations by priests and the faithful from the parish) to Caritas (mainly its headquarters), a marked increase in donations to Caritas in Tarnów were observed from 1942. The action of parochial donations (cash, in-kind contributions) for the Caritas headquarters was the largest one. During the years 1942-1944, cash and in-kind contributions were donated by approx. 30 parishes (approx. 30\%), which were located in 15 deaneries (52\%). In total, PLN 351,445 was donated, mainly from the parishes in the central and western zones of the Tarnów diocese. The generosity of the clergy from their personal income (iura stolae) culminated in 1944, when over 480 priests (compared to 88 in 1940) transferred over PLN 320,000 to Caritas. Financial and material support, as well as donations from the faithful to parochial Caritas branches, did not acquire a universal character, with just isolated cases being recorded in the Tarnów diocese. Locally, however, these funds were the basis of the Caritas' branches' budgets, sometimes even accounting for $3 / 4$ of their income. The subsidies from the Tarnów curia, thanks to the financial policy of Bishop Komar, constituted the most important item in the Caritas budget. By 1944, the curia had donated PLN 2,472,000. It was almost $60 \%$ of the total income of the Association, and more than $78 \%$ of all donations from the Church to the Association.
\end{abstract}

Keywords: World War II; Catholic church; Tarnów diocese; Caritas 